УДК 347.122

DOI https://doi.org/10.32837/pyuv.v0i3(32).598

\author{
Д. С. Спєсівиев \\ orcid.org/0000-0001-7337-7907 \\ кандидат юридичних наук, \\ старший викладач кафедри иивільно-правових дисииплін \\ Східноєвропейського національного університету імені Лесі Українки
}

\title{
ВИЗНАННЯ ПРАВА ВЛАСНОСТІ НА НЕРУХОМІСТЬ У КОНТЕКСТІ ВИМОГИ ЗАКОНУ ПРО ЙОГО ДЕРЖАВНУ РЕЄСТРАЦІЮ: ЕВОЛЮЦІЯ ПРАВОЗАСТОСОВНОГО ПІДХОДУ
}

Постановка проблеми. Проблема правової природи державної реєстрації речових прав на нерухоме майно, а також ії ролі в механізмах первісного виникнення та похідного набуття права власності на нерухомі речі є одним із найбільш важливих юридичних завдань сучасного цивільного права. Від відповіді на питання, чи виникає право власності на нерухомість до його державної реєстрації, яка лише посвідчує відповідний факт, або ж особа стає власником нерухомої речі з моменту державної реєстрації її права власності на відповідне майно, залежить можливість або неможливість застосування такого судового способу захисту права власності, як його визнання в умовах, коли реєстрація такого права з певних причин не проведена.

В основі цієї проблеми лежить сучасний нормативний підхід до регулювання відносин щодо державної реєстрації речових прав на нерухоме майно, а також визначення іï місця в механізмі виникнення та переходу права власності на нерухомість. Одним із її проявів виступає судова практика вирішення справ, зокрема за позовами про визнання права власності, що пов'язані з державною реєстрацією речових прав на спірне нерухоме майно або відсутністю її проведення.

Аналіз останніх досліджень і публікацій. Окреслений спосіб захисту права власності на нерухоме майно ставав предметом розгляду таких учених юристів, як: С.С. Алексєєв, І.В. Андронов, І.В. Венедіктова, І.В. Жилінкова, О.С. Іоффе, А.В. Коструба, О.О. Красавчиков, О.О. Кот, Н.С. Кузнєцова, Р.А. Майданик, В.В. Надьон, О.О. Отраднова, М.О. Рожкова, Я.М. Романюк, І.В. Спасибо-Фатєєва, Л.Г. Талан, Р.О. Халфіна, Г.Г. Харченко, С.М. Хорунжий, Я.М. Шевченко, Р.Б. Шишка, О.Я. Явор, В.Л. Яроцький та ін.

Постановка завдання. Мета статті полягає у визначенні сучасного підходу вітчизняних судів до оцінки ролі державної реєстрації права власності на спірне нерухоме майно в юридичних механізмах його виникнення та переходу, а також встановленні в цьому ключі умов застосування такого способу захисту, як визнання права власності на об’єкт нерухомого майна.

Основний матеріал дослідження. Порушену проблему необхідно розглядати у трьох основних ракурсах, зокрема в контексті положень чинного цивільного законодавства України, тобто в нормативно-правовому ключі, у контексті осмислення відповідного матеріалу на рівні доктрини цивільного права, а також у контексті аналізу відповідних нормативних положень i ї застосування вітчизняними судами.

\section{1. Нормативно-правовий аспект проблеми}

Базовим нормативним положенням Цивільного кодексу України (далі - ЦК України), яке визначає роль державної реєстрації права власності на об'єкт нерухомого майна в юридичному механізмі його первісного виникнення, виступає ч. 2 ст. 331. У разі осмислення цього нормативного припису відокремлено від інших приписів цивільного законодавства України можна дійти висновку, що законодавець запроваджує певну градацію обставин правової реальності, з якими пов'язується виникнення права власності на новозбудований об'єкт нерухомого майна.

Зокрема, за загальними правилом, право власності на нерухомість виникає 3 моменту завершення будівництва (створення майна). Водночас, якщо нерухома річ підлягає прийняттю в експлуатацію, - право власності виникає з моменту такого прийняття, а якщо право власності на нерухомість ще й підлягає державній реєстрації, тоді право власності виникає з моменту його державної реєстрації [1, ст. 331].

Аналогічний підхід, який передбачає певну градацію обставин правової реальності, відображений і у ст. 334 ЦК України, якою визначається можливий склад обставин, що становлять підставу для переходу права власності на нерухоме майно, і взаємозв'язок між ними. Такими обставинами виступають: 1) передача речі; 2) нотаріальне посвідчення договору; 3) державна реєстрація права власності [1, ст. 334].

Проте осмислення цих нормативних положень у контексті зв'язку з іншими приписами чинного цивільного законодавства України показує, що підхід, у рамках якого державна реєстрація права власності розглядається як обставина, з якою пов'язується виникнення такого права у відповідної особи, не є безспірним. Насамперед про це свідчить визначення державної реєстрації речових 
прав на нерухоме майно як офіційного визнання i підтвердження державою фактів набуття, зміни або припинення речових прав на нерухоме майно (п. 1 ч. 1 ст. 2 Закону України «Про державну реєстрацію речових прав на нерухоме майно та їх обтяжень») [2, ст. 2]. Із цього формулювання випливає, що для підтвердження відповідних фактів вони повинні настати раніше за державну реєстрацію, тоді як держава реєстрація цими фактами не є.

\section{2. Доктринальний аспект проблеми}

Відповідний нормативний підхід до визначення правової природи державної реєстрації речових прав на нерухоме майно безпосередньо відобразився і на наукових поглядах стосовно порушеної проблеми. Деякі вчені базуються на ст. ст. 331 та 334 ЦК України, а також на відповідних положеннях Закону України «Про державну реєстрацію речових прав на нерухоме майно та їх обтяжень» і обстоюють погляд, що державна реєстрація прав власності є юридичним фактом - елементом юридичного складу, що являє собою підставу для виникнення права власності на об’єкт нерухомого майна. У зв'язку із цим право власності на нерухомі речі виникає саме з моменту такої реєстрації. Формування такого висновку багато в чому зумовлювалось чіткістю відповідних нормативних положень [3, с. 176].

Однак поглиблення досліджень у відповідній сфері сприяло посиленню аргументації на користь підходу, у межах якого державна реєстрація права власності розглядається в рамках двоєдиної правової природи: і як юридичний факт, і як спосіб фіксації фактів виникнення, переходу та припинення речових прав на нерухоме майно. Щодо цього в цивілістичних дослідженнях зазначається, що державна реєстрація речових прав на нерухоме майно є юридичним фактом і водночас елементом фактичного складу та способом фіксації юридичних фактів. Державна реєстрація не може існувати у формі самостійного юридичного факту і завжди визначається як елемент фактичного складу, адже за своїм визначенням вона має місце як явище, що відбувається після виникнення, переходу або припинення прав на нерухомість. Без таких юридичних фактів не може мати місце і державна реєстрація [4, с. 66].

\section{3. Правозастосовчий аспект проблеми}

Формування судової практики, пов'язаної із застосуванням ст. ст. 331 та 334 ЦК України, а також положень Закону України «Про державну реєстрацію речових прав на нерухоме майно та їх обтяжень», активізувалось у 2013 р., адже саме з 1 січня 2013 р. набрав чинності зазначений Закон у новій редакції. 3 того моменту почала повноцінне функціонування нова система державної реєстрації речових прав на нерухоме майно, що супроводжувалось введенням в експлуатацію но- вого Державного реєстру речових прав на нерухоме майно. Водночас зміни, внесені, зокрема, і до положень ЦК України, ліквідували так звану «подвійну реєстрацію», яка передбачала реєстрацію і правочину щодо нерухомості і речового права на нерухоме майно.

Серед вищих судових інстанцій одним із перших на нововведення відреагував Пленум Вищого спеціалізованого суду України з розгляду цивільних і кримінальних справ, який у своїй постанові від 7 лютого 2014 р. № 5 «Про судову практику у справах про захист права власності та інших речових прав» вказав, що законом не передбачена можливість визнання права власності на новостворене майно й об'єкт незавершеного будівництва в судовому порядку, якщо право власності на таке майно не було зареєстроване раніше в установленому законодавством порядку (абз. 2 п. 15) [5, п. 15].

До 1 січня 2013 р. в Україні функціонував юридичний механізм виникнення права власності на новостворене нерухоме майно, що концептуально не відрізнявся від сучасного юридичного механізму. У зв'язку із цим відповідний підхід вищих судових інстанцій до ролі державної реєстрації права власності на новостворене нерухоме майно почав формуватися ще до зазначеного часу. Зокрема, у своїй постанові від 24 червня 2015 р. у справі № 6-318цс15 Верховний Суд України зазначив, що до прийняття новоствореного нерухомого майна до експлуатації та його державної реєстрації право власності на цей об'єкт не виникає [6]. Такий же висновок зазначений у постанові Верховного Суду України від 6 липня 2016 р. у справі № 3-576гс16 [7] та в інших рішеннях Суду.

Водночас у цей же період відбувається поступове переосмислення правозастосовчого підходу до вирішення відповідної проблеми. Одним із каталізаторів цього процесу виступив, зокрема, принцип обов'язковості судового рішення, а саме необхідність його забезпечення в контексті вимоги державної реєстрації права власності. Проблема полягала в тому, чи можна вважати право власності таким, що виникло на підставі рішення суду до моменту його державної реєстрації.

Щодо цього Вищий господарський суд України у своїй постанові від 24 жовтня 2017 р. у справі № 916/2876/16, зокрема, вказав, що відсутність реєстрації рішення господарського суду Одеської області від 9 грудня 2011 р. у справі № 9/17-4164-2011 як правовстановлюючого документа у відповідному державному реєстрі, як і скасування такої реєстрації, що була здійснена, за умови чинності судового рішення від 9 грудня 2011 р., не впливає на правовий статус відповідного майна, не позбавляє державу Україна права власності, а тому і не надає прав позивачу щодо володіння, користування чи розпорядження ним, 
не наділяє його законними інтересами стосовно такого майна [8].

У подальшому Касаційний господарський суд у складі Верховного Суду у своїй постанові від 27 лютого 2018 р. у справі № 925/1121/17 зазначив, що товариство з обмеженою відповідальністю є власником нерухомого майна, а факт внесення 1 листопада 2016 р. до Державного реєстру речових прав на нерухоме майно приватним нотаріусом відомостей про припинення права власності товариства з обмеженою відповідальністю та запису про право власності на спірне майно за публічним акціонерним товариством на підставі рішення про державну реєстрацію прав та їх обтяжень, a саме іпотечних договорів від 21 травня $2007 \mathrm{p}$. № 18.1/07-ДИ1 та від 31 лютого 2007 р. № 11/07-i, свідчить про порушення прав позивача як власника майна, що слушно зазначили суди попередніх інстанцій [9].

Про переосмислення правозастосовчого підходу до вирішення порушеної проблеми свідчать i виступи суддів Верховного Суду на різноманітних дискусійних і освітніх майданчиках. 3окрема, у своїй доповіді «Судовий захист права власності: актуальні правові позиції Верховного Суду» суддя-спікер судової палати для розгляду справ щодо земельних відносин та права власності Касаційного господарського суду у складі Верховного Суду Юрій Чумак, зокрема, зазначив, що нині суди дійшли висновку, що державна реєстрація не є способом набуття права власності, а лише підтверджує факт набуття речових прав на нерухоме майно [10].

Отже, викладене вище свідчить про те, що нині ми спостерігаємо переосмислення вищими судовими інстанціями ролі державної реєстрації права власності в механізмах його первісного виникнення та переходу між учасниками цивільного обороту. Державна реєстрація не є способом виникнення такого права, а виступає засобом фіксації відповідних обставин правової реальності. У зв'язку із цим відповідний правозастосовчий підхід цілком відповідає положенням чинного цивільного законодавства України і сучасним цивілістичним розробкам у цій сфері $[4$, с. 66]. Основна мета державної реєстрації - підвищити рівень юридичної забезпеченості речових прав, що належать учасникам цивільного обороту. У зв'язку із цим державна реєстрація за своєю телеологічною спрямованістю є юридичним способом охорони суб'єктивних цивільних прав.

Варто погодитись із тим, що в рамках традиційних механізмів виникнення та переходу суб'єктивних цивільних прав на нерухоме майно державна реєстрація є одним з елементів юридичного складу - підстави для виникнення та переходу відповідних прав. У разі створення нової нерухомої речі вона, будучи завершальним елементом складу, посвідчує факт виникнення права власності в конкретної особи, чим забезпечує набуття відповідним майном цивільної оборотоздатності як нерухомої речі. Під час переходу права власності державна реєстрація слугує засобом забезпечення прав набувача, адже з її проведенням факт переходу прав стає загальновизнаним. Водночас необхідно усвідомлювати, що факти виникнення та переходу права власності мають місце до їх державної реєстрації, у зв'язку із чим у разі порушення, невизнання або оспорювання таких прав іншими особами існують передумови для застосування такого способу захисту, як визнання права власності. Адже об'єкт захисту вже існує.

Висновки i перспективи подальших досліджень. Вирішення порушеної проблеми в контексті положень чинного цивільного законодавства України спричиняє набагато глибші наслідки, ніж це може здатись на перший погляд.

Окреслений вище підхід потребує уніфікації в рамках визначених правових ситуацій. Можливість використання такого способу захисту права власності, як його визнання до моменту проведення його державної реєстрації або взагалі незалежно від державної реєстрації права власності, пов'язуеться 3 ризиком, що окреслений Великою Палатою Верховного Суду в постанові від 18 грудня 2019 р. у справі № 14-270цс19, зокрема, коли подача позову про визнання права власності на нерухоме майно пов'язується зі спрощенням або уникненням встановленої законодавством досить тривалої в часі та фінансово затратної процедури оформлення прав на це майно [11]. У зв'язку із цим практика, що формується, повинна передбачати вирішення відповідної проблеми з урахуванням необхідності встановлення юридичних фільтрів для використання відповідного способу захисту.

Наприклад, невиправданим $є$ його використання в ситуаціях, коли право власності особи ніким не оскаржується, зокрема, коли вона не прагнула реалізувати традиційний механізм виникнення або переходу права власності на нерухоме майно в умовах, коли це можливо.

3 іншого боку, такий спосіб захисту прав на нерухомість варто розглядати як ефективний, наприклад, коли відчужувач за договором купівлі-продажу нерухомого майна 3 розстроченням платежів відмовляється передати набувачу заяву про виконання ним свого грошового зобов'язання і відсутність претензій, справжність підпису на якій засвідчено нотаріально відповідно до положень Закону України «Про нотаріат» (якщо такий спосіб посвідчення відповідної обставини передбачено умовами договору).

Також у контексті сформованих висновків виправданим є підхід, окреслений Великою Палатою Верховного Суду в постанові від 19 травня 
2020 р. у справі № 916/1608/18, коли Суд зазначив, що через те, що позивач прагне здійснення державної реєстрації права власності на своє майно, яке він уважає об'єктом нерухомості, належним способом захисту його прав та інтересів $\epsilon$ позовна вимога про визнання права власності на будівлю, споруду, оскільки судове рішення про визнання права власності на будівлю, споруду $е$ підставою для державної реєстрації права власності за позивачем, якщо на момент такої реєстрації власником земельної ділянки, на якій розміщена будівля, споруда, є відповідач, а право власності на будівлю, споруду ні за ким не зареєстроване (п. 93) [12].

Загалом же проведений аналіз показує, що визнання права власності на об'єкт нерухомого майна виступає чи не найефективнішим способом захисту такого права, який може бути використаний в умовах, коли державна реєстрація такого права не проведена. Його ефективність значною мірою підсилена внесенням змін до абз. 12 ч. 2 ст. 16 ЦК України, а також чинними положеннями ч. 2 ст. 5 Цивільного процесуального кодексу України, ч. 2 ст. 5 Господарського процесуального кодексу України. Водночас причини не проведення державної реєстрації можуть бути найрізноманітнішими, від відмови в іiї проведенні державним реєстратором у зв'язку із сумнівами, що відповідна річ є нерухомою, і до наявності спору між співвласниками стосовно часток у новозбудованій нерухомості. Важливим є те, що державна реєстрація права власності виступає способом фіксації фактів виникнення, переходу та припинення права власності на нерухому річ, у зв'язку із чим її відсутність в умовах, коли її проведення без відповідного рішення суду $є$ неможливим, зокрема у зв'язку зі спором щодо відповідної нерухомої речі, повинно розглядатись як обставина, що свідчить про можливість використання відповідного способу захисту.

\section{Jimepamypa}

1. Цивільний кодекс України : Закон України від 16 січня 2003 р. № 435-IV. Відомості Верховної Ради України. 2003. № № 40-44. Ст. 356 (зі змінами).

2. Про державну реєстрацію речових прав на нерухоме майно та їх обтяжень : Закон України від 1 липня 2004 р. № 1952-IV. Відомості Верховної Ради України. 2016. № 1. Ст. 9 (зі змінами).

3. Мартинюк О.А. Проблеми державної реєстрації речових прав на нерухоме майно. Часопис Київського університету права. 2014. № 3. С. 175-177.

4. Спєсівцев Д.С. Реєстрація речових прав на нерухоме майно як конструкція юридичного факту в майнових правовідносинах. Право і суспільство. 2015. № 6-2. Ч. 3. С. $65-70$.

5. Про судову практику в справах про захист права власності та інших речових прав : постанова Пленуму Вищого спеціалізованого суду України з розгляду цивільних і кримінальних справ від 7 лютого 2014 р. № 5 . URL: https://zakon.rada.gov.ua/laws/show/v000574014\#Text (дата звернення: 08.07.2020).
6. Постанова Верховного Суду України від 24 червня 2015 р., судова справа № 6-318цс15. URL: http://reyestr.court.gov.ua/Review/45910640 (дата звернення: 14.07.2020).

7. Постанова Верховного Суду України від 6 липня 2016 р., судова справа № 3-576гс16. URL: http://reyestr.court.gov.ua/Review/58986612 (дата звернення: 14.07.2020).

8. Постанова Вищого господарського суду України від 24 жовтня 2017 р., судова справа № 916/2876/16. URL: http://reyestr.court.gov.ua/Review/69775496 (дата звернення: 14.07.2020).

9. Постанова Касаційного господарського суду у складіВерховногоСудувід27лютого2018р.,судовасправа № 925/1121/17. URL: http://reyestr.court.gov.ua/ Review/72616760 (дата звернення: 14.07.2020).

10. Суддя-спікер КГС ВС Юрій Чумак взяв участь y IV Міжнародному форумі із захисту бізнесу. URL: https://supreme.court.gov.ua/supreme/pres-centr/ news/710350/ (дата звернення: 15.07.2020).

11. Постанова Великої Палати Верховного Суду від 18 грудня 2019 р., судова справа № 14-270цс19. URL: http://reyestr.court.gov.ua/Review/87144996 (дата звернення: 14.07.2020).

12. Постанова Великої Палати Верховного Суду від 19 травня 2020 р., судова справа № 916/1608/18. URL: http://reyestr.court.gov.ua/Review/89819917 (дата звернення: 15.07.2020).

\section{Анотація}

Спєсівцев Д. С. Визнання права власності на нерухомість у контексті вимоги закону про його державну реєстрацію: еволюція правозастосовного підходу. - Стаття.

Стаття містить результати наукового дослідження особливостей використання визнання права власності на нерухоме майно як способу захисту суб'єктивних цивільних прав в умовах вимоги закону про державну реєстрацію такого права.

Автор порушує актуальну практичну проблему можливості використання такого способу захисту права власності тоді, коли право особи на відповідне майно не зареєстроване, хоча законом встановлюється обов'язковість його державної реєстрації. Причиною такої проблеми $є$ положення чинного цивільного законодавства України, зокрема Закону України «Про державну реєстрацію речових прав на нерухоме майно та їх обтяжень», якими встановлюється, що речові права на нерухоме майно та їх обтяження, що підлягають державній реєстрації відповідно до закону, виникають із моменту такої реєстрації. Із цього мало б випливати, що відсутність державної реєстрації права власності на нерухому річ означає і відсутність факту виникнення відповідного права, а тому і можливості його визнання в судовому порядку.

Звертаючись до сучасних цивілістичних розробок, а також окремих положень чинного цивільного законодавства України, автор обстоює позицію, що факти виникнення та переходу права власності на нерухоме майно мають місце до його державної реєстрації, у зв'язку із чим у разі порушення, невизнання або оспорювання такого права іншими особами до моменту його реєстрації наявні передумови для застосування такого способу захисту, як визнання права власності.

Окрема увага у статті приділена аналізу позицій вищих судових інстанцій щодо порушеної проблеми, а також їхньої еволюції у процесі формування судової практики. 
Автор констатує, що визнання права власності на об'єкт нерухомого майна виступає чи не найефективнішим способом захисту такого права, що може бути використаний в умовах, коли державна реєстрація такого права не проведена. Його ефективність значною мірою підсилена внесенням змін до абзацу 12 частини 2 статті 16 Цивільного кодексу України, а також чинними положеннями частини 2 статті 5 Цивільного процесуального кодексу України, частини 2 статті 5 Господарського процесуального кодексу України.

Ключові слова: нерухомість, речові права, державна реєстрація, визнання права власності.

\section{Summary}

Spiesivtsev $D$. S. The recognition of property right on immovable thing in context of legislative demand of its state registration: evolution of right-enforcement approach. - Article.

The article contains the results of scientific research of the features of usage of such way of protection of subjective civil right on immovable thing as its recognition in context of legislative demand of state registration of such right.

The author raised the actual issue of possibility of using such way of protection of property right in situation when person's right on appropriate things was not registered but the law provides the mandatory registration of it. The author see the reason of such a problem in current legislative provisions of Ukraine, particularly provisions of Law of Ukraine "On State Registration of Corporeal Rights to Real Estate and Their Encumbrances" which provide that corporeal rights on immovable property and their encumbrances, that are subject to registration according to law, are arise from the moment of its registration. At author's opinion it should follow that the absence of state registration of property right on immovable thing means the absence of appropriate right and therefore impossibility of its protection.

Turning to the modern juridical researches in civil law as well as to the current legislative provisions of Ukraine the author defends a position that facts of arising and transfer of right of property right on immovable things take place before registration of such rights. In relation to that in situation when property right is violated or not recognized or disputed by other person the all necessary conditions of using of such way of it protection as recognition of property right are exist.

The considerable attention in the article is devoted to the review of juridical positions of the highest courts devoted to appropriate problem and to consideration their evolution during judicial practice formation.

The author states that recognition of property right on immovable thing is one of the most effective ways of appropriate right protection that can be used in conditions when state registration of such a right was not conducted. Its effectiveness is strengthened with amendments to paragraph 12 of part 2 of article 16 of Civil Code of Ukraine and with current provisions of part 2 of article 4 of Code of Civil Procedure of Ukraine and of part 2 of article 4 of Code of Commercial Procedure of Ukraine.

Key words: immovable property, corporeal rights, state registration, recognition of property right. 